\title{
EVALUATION OF A HYBRID SYSTEM OF RENEWABLE ELECTRICITY GENERATION FOR A REMOTE AREA OF COLOMBIA USING HOMER SOFTWARE
}

\section{EVALUACIÓN DE UN SISTEMA HIBRIDO DE GENERACIÓN DE ENERGÍA RENOVABLE PARA UN ÁREA REMOTA DE COLOMBIA USANDO EL SOFTWARE HOMER}

\begin{abstract}
Subsequent to the study of the energy demand and the evaluation of possible available resources in the remote area of Riosucio, Chocó region, Colombia, an analysis is performed on the implementation of three alternative systems of power generation. The first is a micro hydroelectric power station on the Truando River, which includes the design using HOMER software simulation, the costs of building and implementation, and its share in the energy mix. The second system is an array of photovoltaic panels in isolated configuration. This will include the design, via HOMER software simulation, of batteries, panel distribution, inverters, and connections, for a usable specific area restricted by the limited solar resource of the area. Finally, wind power is analyzed, a system that will include the determination of the most suitable turbine for the available wind resource in the area, as well as the analysis of the ideal quantity of wind generators based on its share in the energy mix For each of the assessed systems, a financial analysis and the feasibility are obtained, based on the investment, percentage of energy, and the electricity savings for each of the homes.
\end{abstract}

Keywords: Renewable Energy, HOMER Software, Energy Mix, Simulation, Generation Isolated Areas.

\section{RESUMEN}

Posterior al estudio de la demanda energética y evaluación de los posibles recursos disponibles en la zona aislada de red eléctrica, de Riosucio Chocó en Colombia, se plantea un análisis de implementación de tres sistemas alternativos de generación: Una microcentral hidroeléctrica en el río Truando, el cual incluye el diseño por simulación con HOMER software además de los costos de construcción e implementación, así como su porcentaje energético de participación; un arreglo de paneles fotovoltaicos, en configuración aislada que incluirá el diseño por simulación con HOMER software de baterías, distribución de los paneles, inversores y conexiones, para un área específica aprovechable teniendo como limitante el recurso solar de la zona, y por último generación con energía eólica, sistema que incluirá la determinación de la turbina más apta para el recurso eólico disponible en la zona, así como el análisis la cantidad óptima de generadores eólicos, basándose en la De cada uno de los sistemas dimensionados se obtiene un análisis financiero, 
y de pre factibilidad según la inversión, porcentaje de participación energética, y el ahorro de energía eléctrica para cada una de las viviendas.

Palabras claves: Energía Renovable, HOMER Software, Mix Energético, Simulación, Generación Zonas Aisladas. 